\title{
SCHOOL MANAGEMENT INSPIRATION IN FUTURE TEACHERS' TRAINING
}

\section{[INSPIRACE SKOLSKEHO MANAGEMENTU V PRIPRAVE BUDOUCICH UCITELU]}

\author{
Vaclav Trojan
}

doi: 10.18355/PG.2018.7.1.5

\begin{abstract}
Future teachers' training has often been criticised in the last period as a result of its single-sided focus on subject education. Furthermore, insufficient teacher training may result in discrepancies in expectations of school directors who entrust them with a wide scale of various activities to assure proper running of the educational process immediately after the graduates of faculties of education have been employed. Training of future teachers is often regarded insufficient.
\end{abstract}

\section{Key words}

school management, future teachers' training, primary school, school director, the Czech Republic

\section{Anotace}

Př́íprava budoucích učitelů je v poslední době často kritizována pro svoje jednostranné oborové zaměření. Navíc se jejich nedostatečná připravenost může dostat do rozporu s očekáváním samotných ředitelů škol, nebot' ti je po nástupu absolventů fakult vzdělávajících učitele pověřují celou škálou různých činností nutných pro zajištění správného průběhu pedagogického procesu. Připravenost budoucích učitelů na práci je často nedostačující.

\section{Klíčová slova}

školský management, příprava budoucích učitelů, základní škola, ředitel školy, Česká republika

\section{Úvod}

Současná realita škol ukazuje jako veliký problém začínajících učitelů jejich nedostatečnou připravenost na práci mimo třídu. Nepřipravenost na adekvátní komunikaci s rodiči, špatná orientace v potřebných dokumentech, problematika práce mimo prímou vyučovací povinnost, prííprava nejrůznějších akcí či zvládání problémových žáků mohou ve svém důsledku vést až k odchodu učitelů mimo školu či vzdělávací systém (Trojan, 2017).

Cílem prŕspěvku je poukázat na význam školského managementu v pregraduální prrípravě budoucích učitelů. Ukazuje se totiž, že př́iprava studentů akcentující oborovou prŕpravu, popr. pedagogickou praxi směřovanou do vyučovací hodiny nesplňuje potřebný a žádoucí komplexní profil absolventa studia učitelství a nepřipravuje jej v plné míře na výkon jeho budoucí profese. 
Východiskem sdělení je kritický popis stávající situace v přípravě budoucích učitelů, které se kromě devíti pedagogických fakult v České republice věnuje přes padesát dalších fakult vzdělávajících učitele. Právě malé sepětí s praxí je často kritizováno nejen řediteli z terénu, ale často samotnými studenty a je patrno na jejich aktivitách (např. studentská iniciativa Otevřeno). Dalším východiskem je neschválení navrhované podoby kariérového systému učitele, který právě v době psaní textu Poslanecká sněmovna definitivně odsunula. Autor se tomuto citlivému tématu již věnoval na konferenci ICOLLE 2017 ve Křtinách u Brna, nyní přidává další rovinu svého výzkumného šetření. V jiných textech se autor věnoval situaci ve vzdělávání ředitelů škol (Trojan, 2016), kde pojmenovával úskalí plynoucí z neexistence systémové podpory, stejná situace platí právě pro samotné učitele. Jejich další rozvoj záleží na nich samotných a podpora je pouze v rukou ředitele školy, který podle svého přesvědčení a v neposlední řadě i podle finančních možností školy podpoří či nepodpoří učitelův další rozvoj.

Učitelské povolání nestojí jenom na znalosti vyučované látky. Dobrý učitel musí být všestranně vzdělaná osobnost s psychologickými, řečnickými, manažerskými i dalšími kompetencemi (Prucha, 2012). Musí být osobností, která si dokáže vydobýt respekt, stát si za svým a zároveň být ochotna se neustále vzdělávat a zdokonalovat. Učitelské povolání není zdaleka pro každého a ne každý může být dobrým učitelem. Je evidentní, že v jeho př́ipravě musejí být kromě oborové a didaktické přípravy začleněny i jiné oblasti směřující právě ke komplexnosti profese. Zajímavou možností bylo zakomponování tzv. klinické školy do př́ípravy učitelů (Bendl, 2011), však vzhledem k ukončení výzkumného projektu uvízla tato myšlenka na mrtvém bodě.

Autor př́ispěvku reflektuje několikaletou činnost specializovaného pracoviště Centrum školského managementu Pedagogické fakulty Univerzity Karlovy zaměřenou právě na eliminaci těchto problémů. Tým jeho pracovníků převážně složený z odborníků schopných výzkumně i pedagogicky spojovat teorii s autentickým školským terénem je prostřednictvím studentů oboru Školský management (zejména ředitelů či jejich zástupců) každodenně konfrontován s názory pedagogických pracovníků.

První část výzkumu a dílčí závěry byly autorem prezetovány na konferenci ICOLLE 2017 (Trojan, 2017), v tomto příspěvku se některá data opakují a jsou uceleně zpracována a komparována.

Autor přináší jednak názor ředitelů českých základních škol na podobu vybraných kompetencí nastupujícího učitele, tedy absolventa některé z fakult připravujících učitele. Tento názor je poměrně plastický, nebot' je složen ze závěrů dotazníkového šetření a závěrů jednání kulatého stolu, který se přesně této problematice věnoval a po níž ještě organizátoři využili skupinu ředitelů $\mathrm{k}$ další diskuzi a reflexi situace. Dále přináší názory účastníků výběrového semináře Základy školského managementu, což byli studenti učitelských oborů pedagogické fakulty připravující se na vstup do učitelské profese a často kriticky reflektující některé složky jejich vzdělávání.

Dalším cílem příspěvku je proto komparace názorů ředitelů škol a budoucích absolventů učitelství, která přináší zajímavé názory a bohužel predikuje rozpory a úskalí budoucího stavu. V některých bodech se totiž tyto dvě cílové 
skupiny značně rozcházejí a přitom budou moci být členy jednoho pedagogického sboru. Učitetel je nezpochybnitelným činitelem rozvoje kvalitní školy. Téma učitele, jeho socioprofesní role, klíčové profesní kompetence, tvưrčí charakter jeho činností, profesní autonomie, postojově etické kvality a další jsou jedním z profilujících témat českého i mezinárodního pedagogického výzkumu. (OECD 1994; Spilkova, Vasutova 2002; Vasutova 2004; Walterova 2004; Spilkova, Vasutova 2008, Voda 2015) Společným východiskem zvýšeného zájmu o tyto oblasti je skutečnost, že s rostoucím významem vzdělávání ve společnosti vědění úzce souvisí otázka kvality učitelů a jejich profesionalizace. Učitelé jsou považováni za klíčové hráče na poli vzdělávacích reforem a inovací. Současně je zdůrazňováno, že v kontextu měnící se české společnosti a systému vzdělávání se nároky na učitelskou profesi zásadním způsobem posouvají. (Spilkova, Vasutova 2008). Vůdčím tématem $v$ úvahách o učitelské profesi je kvalita učitele a jejich odpovědnost za kvalitu výuky, které se aktualizují s rostoucím významem vzdělávání ve společnosti vědění. $\mathrm{V}$ souvislosti $\mathrm{s}$ tím můžeme v posledních dekádách vysledovat četné výzkumné či vývojové projekty věnovaných kvalitě učitelů, zjištování jejich profesního výkonu, identifikaci klíčových profesních kompetencí učitele a formulacím profesního standardu jako nástroje pro vzdělávání, profesní rozvoj a hodnocení učitelů. Mnoho výzkumů přitom prokázalo, že kvalita učitelů je nejdůležitějším faktorem ovlivňujícím kvalitu školního vzdělávání a výsledky žáků (DarlingHammond 2000; Hanusek, Kain, Rivkin 2005).

Bylo již dříve uvedeno, že obor školský management není dosud součástí pregraduální přípravy budoucích učitelů. Tento obor odpovídá na řadu otázek, které neumí zodpovědět jiný obor, přitom jsou pro něho primární aspekty vzdělávání, nikoli byrokratické zabezpečení školy, jak je někdy chápáno pod vlivem neoliberálního pojetí vzdělávání i pojetí samotného ředitele školy srovnávaného s manažerem kterékoli firmy (Faltysek et al., 2015). Obor bývá často zužován pouze na prŕpravu ředitelů škol. Tyto důležité a nezastupitelné osoby jsou stě̌̌ejní pro rozvoj školy, však okruh cílových skupin oboru je mnohem širší. Uvedené zúžení je determinováno legislativním rámcem České republiky, nebot' např. na rozdíl od Slovenska je $\mathrm{z}$ vedoucích pedagogických pracovníků pouze ředitel školy jakkoli ukotven $\mathrm{v}$ zákoně 561/2004 Sb. (tzv. školský zákon) a zákoně 563/2004 Sb. o pedagogických pracovnících, vždy v platném znění.

Existují ovšem oblasti, problémy a postupy, které jiný obor nemá, nezabývá se jimi a tím pádem nikdo jiný než školský management nemůže zdůvodnit vědecké ukotvení a jeho paradigmata. Nezbytností školského managementu interdisciplinární pohled. Školský management je svébytnou specifickou disciplínou s vymezeným oborem zkoumání, která nemůže být nahrazena či suplována blízkými disciplínami. Řízení školy a školství se vyznačuje zásadními specifiky, která obor vymezují vzhledem $\mathrm{k}$ obecnému managementu a teorii rrízení na straně jedné i pedagogice či andragogice (Veteska, 2016) na straně druhé.

Obor školský management (Everard \& Morris, 1996) zkoumá nejrůznější aspekty ř́zení školy v měnících se podmínkách (Trunda, 2012) a jako takový 
musí reflektovat vývoj, dosavadní stav i trendy oboru, stejně tak i trendy vývoje (Covey, 1991) společnosti a školství okolních zemí.

V českém prostředí je v přípravě budoucích učitelů školský management dosud podceňován. Na rozdíl od situace na Slovensku (Obdrzalek, Polak, 2007), kde je zařazován dokonce jako součást státní závěrečné zkoušky (Pisonova, 2014), je na českých vysokých školách realizován maximálně formou výběrového předmětu, tudíž drtivá většina budoucích učitelů se s poznatky tohoto oboru vůbec nesetká.

\section{Použité metódy}

Výzkumné šetření popisované v tomto příspěvku probíhalo ve dvou etapách. V první etapě byli osloveni ředitelé čekých základních škol. Základním nástrojem použitým pro získání jejich názorů byl elektronický dotazník, který byl dále doplněn verbalizovanými závěry $\mathrm{z}$ kulatého stolu, jenž byl realizován v roce 2013 na PedF UK pod názvem Jakého učitele - absolventa potřebují ředitelé školy? Názory ředitelů škol byly komparovány s názory účastníků výběrového semináře Základy školského managementu v letech 2014 - 2016.

Ředitelé škol byli osloveni prostřednictvím elektronického dotazníku v měsíci lednu a únoru 2013 v rámci př́ípravy uvedeného kulatého stolu. Šlo o ředitele českých základních škol, ze 158 náhodně vybraných ředitelů z celé České republiky odpovědělo 132 , tj. návratnost dotazníku byla $83,5 \%$, počet kladně reagujících respondentů $\mathrm{N}=132$. Vzhledem k charakteru orientačního šetření nebyla brána do úvahy velikost školy, její umístění či délka praxe ředitele školy. Jednotlivé školy byly vybrány ze školského rejstř́iku MŠMT ČR pomocí generátoru náhodných čísel.

$\mathrm{Na}$ kulatém stole byly prezentovány tyto ředitelské názory, o nichž bylo diskutováno a po skončení ještě autor šetření inicioval menší ohniskovou skupinu v počtu čtyř ředitelů, kde byla pojmenovávána klíčová úskalí v př́ipravě budoucích učitelů na fakultách vzdělávajících učitele.

Ve druhé etapě výzkuného šetření bylo pracováno s názory studentů učitelských oborů. Dalším zdrojem výzkumných dat bylo proto šetření názorů účastníků výběrového semináře Základy školského managementu. Toto šetření bylo realizováno vždy v úvodu jednosemestrálního běhu tohoto předmětu v letech 2014-2016 a celkově se do něho zapojilo 98 studentů. Studenti byli dotazováni totožným způsobem, proto je možno jejich názory použít kompaktně jako názory jedné skupiny respondentů.

Posledním výzkumným zdrojem byla skupinová reflexe 24 studentů po skončení celého semináře v červnu 2016, což zajistilo plasticitu názorů a nezbytnou míru triangulace (Skutil, 2011)

Cíle šetření byly v souladu s Maxwellem (Svaricek, Sedova, 2007) stanoveny v rovině intelektuální, praktické i personální. Autor je přesvědčen, že získané poznatky jednak poslouží khlubšímu ukotvení oboru jako součásti pedagogiky, dále budou použity pro praktické návrhy učitelské přípravy, stejně tak rozšírí obzory výzkumníků samotných. 


\section{Výsledky}

V rámci dotazníkového šetření byl získán soubor odpovědí respondentů $(\mathrm{N}=132)$. Tito byli dotazováni na úroveň kompetencí, jimiž byli vybaveni učitelé nastupující v posledních dvou letech na jejich školu. Na první pohled (viz obrázek č.1) je patrný rozdíl mezi oborovými znalostmi, s nimiž přicházejí absolventi z fakult vzdělávajících učitele a např. jejich schopností zvládat krizové situace, připravenost vést ostatní či schopnost práce v týmu. Právě tyto kompetence jsou očekávatelně důležité $\mathrm{v}$ týmovém pojetí školy, kdy společná práce na inovacích školních vzdělávacích programů i každodenní pedagogická práce vyžaduje vysokou míru rozhodnosti a může nastupujícího učitele $\mathrm{v}$ relativně krátké době dostat do situace, kdy bude muset týmově pracovat, popř. kdy bude pověřen vedením třeba malého týmu svých spolupracovníků.

Názory ředitelů byly navíc chápány ve dvou časových rovinách. Jednak byli ředitelé dotazováni na jejich názor na aktuální připravenost absolventů učitelských vzdělávacích programů, tedy nastupujících učitelů, jednak měli ředitelé základních škol vyjádřit hodnotu, kterou by oni sami potřebovali tedy jak by měl vypadat absolvent $\mathrm{v}$ ideálním príípadě. Je zajímavé, že všechny hodnoty by ředitelé potřebovali vyšší s výjimkou oborových znalostí. Ty už od absolvenů očekávají tak vysoké, že vlastně připouštějí jejich snížení.Ukazuje se komplexnost učitelských kompetencí, mezi nimiž bude zřejmě oborové vymezení postupně upozad'ováno.

Na druhé straně je potěšující vysoká míra hodnocených kompetencí právě v oblasti oborové, didaktické i komunikace s žáky, což vytváŕí dobrý základ pro následnou práci s nastupujícím učitelem $\mathrm{v}$ rámci jeho kariérového rozvoje v nejširším slova smyslu.

Vždy je uváděna hodnota současný stav - potřeba: Oborové znalosti $(9$ 6,9), didaktické schopnosti $(6,5$ - 8,9), komunikace s žáky $(5,8-8,7)$, komunikace s dospělými $(4,5-8,7)$, schopnost týmové práce $(3,4-6,5)$, připravenost vést ostatní $(2,1-6,4)$, schopnost zvládat krizové situace $(1,1-$ $7,1)$. U poslední položky je cítit největší mezera ve srovnání se všemi položkami. 


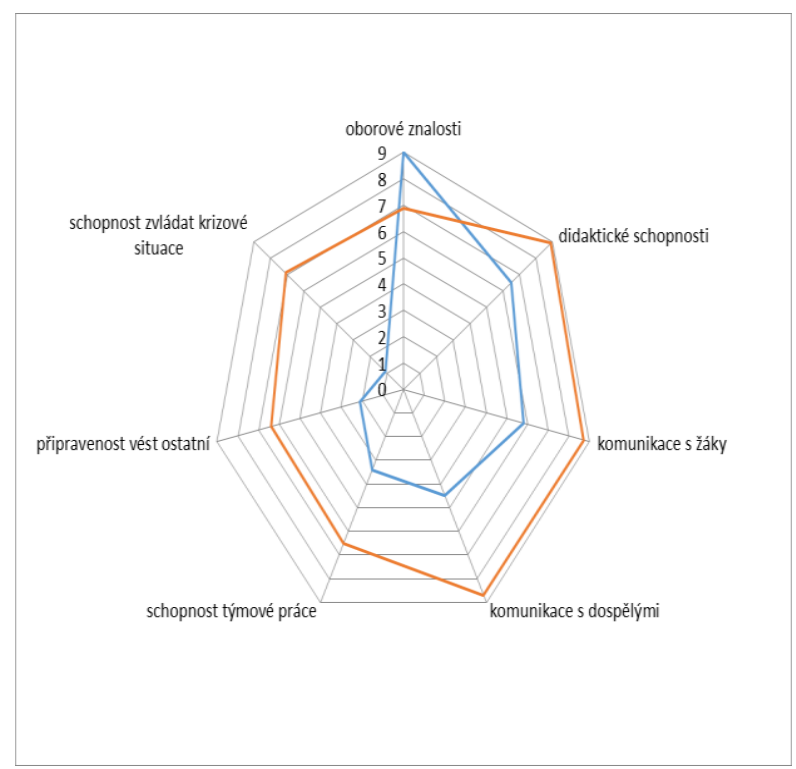

\section{Obrázok 1 Názory ředitelů škol}

Názory ředitelů škol získané dotazníkovým šetřením byly konfrontovány s názory účastníků již zmíněného kulatého stolu a zejména súčastníky fokusové skupiny $(\mathrm{N}=4)$, která se sešla po skončení kulatého stolu a dlouze reflektovala jednak jednání samotného kulatého stolu, jednak svoje zkušenosti s nastupujícími absolventy. Do fokusové skupiny byli vybráni právě ředitelé $\mathrm{s}$ větší zkušeností $\mathrm{s}$ touto cílovou skupinou, všichni čtyři ředitelé měli více než tři nastupující absolventy v průběhu uplynulých dvou let.

Klíčovými slovy získanými důkladným rozborem diskuze vedené v této skupině byly zejména: nepřipravenost na běžný školní život, neznalost ŠVP a dalších běžných školních pojmů, překvapení nastupujících absolventů ze skutečné reality, obavy z jednání s rodiči, nesplnitelná očekávání absolventů, nechut' akceptovat pravidla školy, malá odolnost v nestandardních situacích. Tyto názory jsou ve shodě s výsledky výše popsaného dotazníkového šetření a ukazují, že právě prvky školského managementu v jejich prrípravě vůbec zakomponovány nebyly.

Dotazníky zaměřené na názory samotných studentů učitelských oborů byly strukturovány shodně s dotazníky pro ředitele, aby bylo možno později komparovat názory obou cílových skupin. Studenti byli dotazování na vlastní subjektivní pocity úrovně určitých kompetencí, studenti reflektovali svůj názor na připravenost na učitelskou profesi, jednalo se vždy o studenty magisterského studia, tedy v relativně krátké době před ukončením studia. Stejně jako ředitelé byli i oni přesvědčeni o vysoké míře svých oborových znalostí (více na obrázku č.2), leč nejvyšší hodnotu uváděli v oblasti vlastní připravenosti pro komunikaci $\mathrm{s}$ dospělými, dále bude komparace více komentována a načrtnuty případné neshody. 
Studenti byli také požádáni o dvě roviny svých odpovědí, aby bylo možno komparovan jejich názor na aktuální připravenost a požadovaný budoucí stav.

Také zde je uváděna hodnota současný stav - potřeba: Oborové znalosti $(7,8$ - 7,1), didaktické schopnosti $(5,8-8,4)$, komunikace s žáky $(7,6-7,6)$, komunikace s dospělými $(8,6-6,4)$, schopnost týmové práce $(6,4-7,1)$, prripravenost vést ostatní $(4,8-4,9)$, schopnost zvládat krizové situace $(5,9-$ $8,9)$. U poslední položky je stejně jako v případě ředitelů škol cítit největší mezera ve srovnání se všemi položkami.

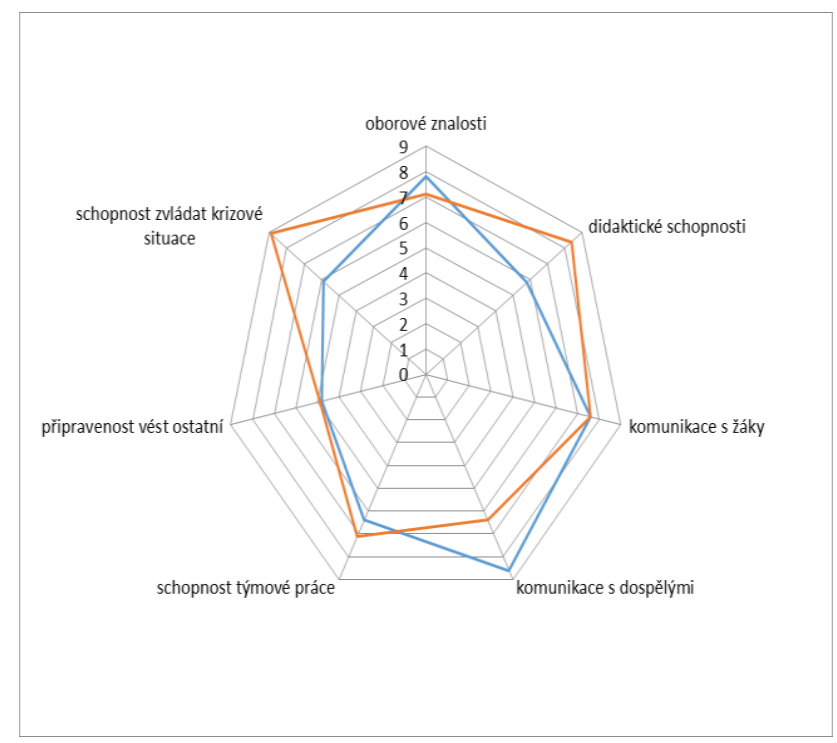

\section{Obrázok 2 Názory studentů}

Je namístě klást otázky, proč dochází $\mathrm{k}$ tak velikým rozporům a rozdílům mezi odpověd'mi ředitelů škol a absolventů učitelských studijních programů. Zajímavé je srovnání názorů získaných $\mathrm{v}$ obou dotazníkových šetřeních (více na obrázku č.3), z komparace vyplývá několik zásadních skutečností:

Obě skupiny (ředitelé i studenti) cítí, že absolventi jsou poměrně dobře oborově připraveni i mají odpovídající míru didaktických schopností. V ostatních oblastech vždy studenti uváděli vyšší hodnoty, jsou tedy možná sebevědomější a přesvědčeni o dobré připravenosti, což je v rozporu s pojmenovávanou malou znalostí školského terénu. Rozpor není veliký v oblasti komunikace $s$ žáky, vyšší hodnoty nebývá oblast připravenost vést ostatní a schopnost týmové práce, však nejvyšší rozpor mezi názory je $\mathrm{v}$ oblastech komunikace $\mathrm{s}$ dospělými a zejména schopnost zvládat krizové situace. V posledních čtyřech oblastech je vidět jasná nespokojenost ředitelů s úrovní přicházejících absolventů.

Autor příspěvku je přesvědčen, že absolventům budou chybět zásadní kompetence potřebné pro výkon učitelské profese a že je třeba vyvíjet tlak na inovaci společného základu studia učitelství v blížící se akreditaci. Výsledky šetření potvrzují tento názor a mohou být využity jako argumentační podklad pro jednání s garanty studijních oborů. 


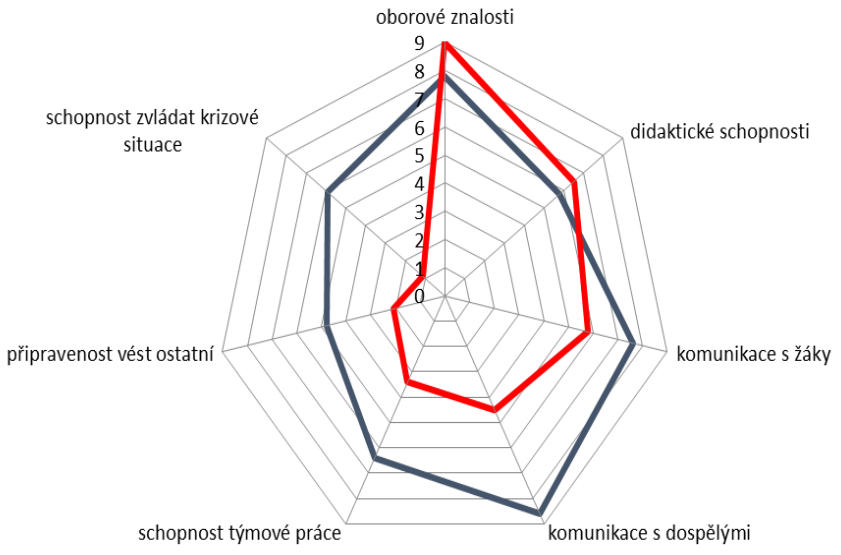

\section{Obrázok 3 Komparace názorů studentů a ředitelů škol na současný stav}

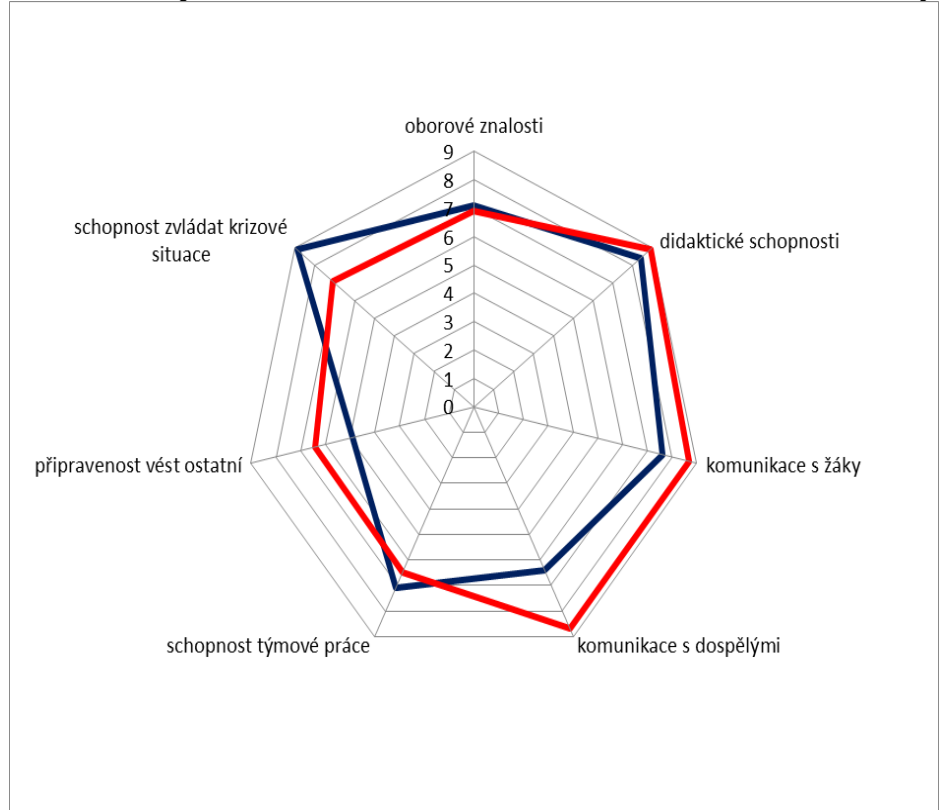

\section{Obrázok 4 Komparace potřeb studentů a ředitelů škol}

Z obrázku vyplývá zásadní skutečnost. Studenti, tedy budoucí učitelé i samotní ředitelé základních škol cítí veliký tlak, který je na výkon práce učitele kladen, tímto lze vysvětlit vysoké hodnoty ideálního stavu u skupiny budoucích učitelů i ředitelů škol. Budoucí učitelé kladou nejvyšší hodnotu na 
položku schopnost zvládat krizové situace, ředitelé škol dokonce tři položky - didaktické schopnosti, komunikace s žáky a komunikace s dospělými.

\section{Záver}

Příspěvek se zabýval jedním z problémových míst přípravy budoucích učitelů na fakultách vzdělávajících učitele, zaměřoval se na studenty pregraduálního studia, kteří nemají vlastní zkušenosti s výukou a prací se žáky mimo jejich pedagogické praxe. Autor vycházel ze současné situace ve vzdělávacích programech pro budoucí učitele, které v minimální míře posilují kompetence učitele potřebné pro práci mimo třídu. Pro formulaci svých tvrzení použil vlastní dotazníková šetření, která realizoval v letech 2014 - 2016 a výsledky realizovaných ohniskových skupin (focup group) složených z ředitelů českých základních škol a studentů učitelství.

Lze oprávněně tvrdit, že stávající podoba př́ípravy budoucích učitelů není komplexní a dostatečná. Ačkoli nebyla dosud realizována reprezentativní šetření, je možno i ze stávajících výsledků dobře pojmenovat aktuální nedostatky, které mohou být komplikujícími faktory v budoucnosti.

Ředitelé škol zejména ve velkých městech se v současné době potýkají s radikálním nedostatkem absolventů některých aprobací, patrno to je zejména u učitelů primární pedagogiky, matematiky a fyziky. Je proto velice rychle zvážit, zdali by dokonalejší př́íprava budoucích učitelů nepomohla tuto situaci částečně řešit tím, že by budoucí učitelé byli lépe připraveni a neodcházeli po několika měsících či letech mimo vzdělávací systém. Je veliká škoda, když studenti několik měsíců před absolvováním svého studia nejsou komplexně pro svoji práci připraveni a v horším případě mají zkreslené představy o autentickém školském prostředí. Komparace názorů obou skupin je více než znepokojivá.

Realizovaný výzkum i příspěvek vznikl za podpory projektu PROGRES Q17 (UK Praha)

\section{Bibliographic references}

BENDL, S. et al. 2011. Klinicka skola: misto pro vyzkum a praktickou pripravu budoucich ucitelu. Praha: PedF UK, 553 s., ISBN 978-80-7290-5171

COVEY, S. 1991. Principle-centered Leadership. New York: Free Press, 1991.

DVORAK, D. 2011. Pedagogicke vedeni skoly: hledani zdroju a obsahu pojmu. Orbis scholae. Praha: PedF UK, roc. 5, c. 3, s. 9 - 25.

EVERARD, K. B. - MORRIS, G. 1996. Effective School Management. London.

FALTYSEK, P. et al. 2015. Vzdelavaci lidr - Zkusenosti s realizaci vzdelavaciho programu pro vedouci pracovniky ZS. Praha: Ceska skolni inspekce, 52 s. ISBN 978-80-88087-03-8.

OBDRZALEK, Z. - POLAK, J. 2007. Aktualne otazky skolskeho managementu. Nitra: Pedagogicka fakulta, 120 s. ISBN 978-80-8094-087-4 
PISONOVA, M. et al. 2014. Skolsky management pre studijne odbory ucitelstva a pripravu veducich pedagogickych zamestnancov. Bratislava: UK Bratislava, 201 s. ISBN 978-80-223-3621-5.

PRUCHA, J. 2015. Ceska vzdelanost. Praha: Wolters Kluwer, 208 s. ISBN 978-80-7478-675-4.

PRUCHA, J. 2002. Ucitel. Soucasne poznatky o profesi. Praha: Portal, 154 s. ISBN 80-7178-621-7

TROJAN, V. 2016. Neresene otazky profesni pripravy reditelu skol a jejich dalsiho rozvoje. In: Andragogicka revue 1/2016, str. 62-70,

TROJAN, V. 2017. Prvky skolskeho managementu v priprave budoucich ucitelu. In.: Sbornik z mezinarodni vedecke konference ICOLLE 2017, Brno: Mendelova univerzita v Brne, s. 235-243, ISBN 978-80-7509-503-9

TROJAN, V. 2017. Rizeni pedagogickeho procesu v soucasne skole. Praha: PedF UK ISBN 978-80-7290-961-2.

TROJAN, V. - TROJANOVA, I. - TRUNDA, J. 2015. Vybrane kapitoly ze skolskeho managementu pro ucitele. Praha: Univerzita Karlova v Praze,

ISBN 978-80-7290-868-4

TROJAN, V. 2015. Pristupy k managementu vzdelavani v kontextu Ceske republiky. Praha: PedF UK, 84 s. ISBN 978-80-7290-867-7.

TRUNDA, J. 2012. Rizeni skoly ve znalostni spolecnosti. Praha: PedF UK, s. 88. ISBN 978-80-7290-541-6.

VETESKA, J. 2016. Prehled andragogiky. Praha: Portal, 320 s. ISBN 97880-2622-1026-9.

VODA, J. 2015. Nove profesni vyzvy ucitele po jmenovani reditelem skoly. Pedagogika. Sv. 2, ISSN 0031-3815.

PhDr. Václav Trojan. PhD.

Centrum školského managementu

Pedagogická fakulta Univerzity Karlovi

Myslíkova 7, 11000 Praha 1

Česká republika

vaclav.trojan@pedf.cuni.cz 